\title{
A review of antioxidant and anti-acetylcholinesterase activities of Centella asiatica (L.) Urb. for the treatment of Alzheimer's disease
}

\author{
Abbas, S., Latif, M.S., Shafie, N.S., Ghazali, M.I., Abidin, N.A.Z., Mustafa, M.K. and \\ *Kormin, F. \\ Department of Technology and Natural Resources, Faculty of Applied Sciences and Technology, Universiti \\ Tun Hussein Onn Malaysia (UTHM), Kampus Pagoh, KM1, Jalan Panchor 84000 Muar, Johor, Malaysia
}

\begin{abstract}
Article history:
Received: 27 October 2019

February 2020

Accepted: 26 May 2020

Available Online: 27

December 2020

Keywords:

Antioxidant,

Acetylcholinesterase,

Medicinal plants,

Centella asiatica,

Alzheimer's disease,

Dementia
\end{abstract}

Received in revised form: 14

DOI:

https://doi.org/10.26656/fr.2017.5(2).355

\section{Introduction}

Alzheimer's disease (AD) is the most common worldwide dementia disorder of old age that is still incurable even after more than a hundred years of its discovery. Due to its worldwide prevalence and progressive nature, $\mathrm{AD}$ has high social and economic impacts on society (Franceschi et al., 2018). Referring to 50 million dementia patients worldwide in 2018, it is expected that the number of dementia patients will rise to 82 million by 2030 , and 152 million by 2050 . In 2018 , US\$ 1 trillion were spent worldwide on the treatment of dementia and it is expected that this number would double by 2030 . There were 9.9 million newly reported dementia cases around the globe, that is, a new dementia case every 3 seconds (Patterson, 2018). The adverse changes in the brain for the development of AD include extraneuronal deposition of protein amyloid $\beta$ (known as beta-amyloid plaques) along with the deposition of an abnormal tau protein inside the neurons (known as tau tangles). These pathological brain changes lead to neurodegeneration (Chen and Mobley, 2019) and have been linked to a variety of etiological factors like neuroinflammation, neuronal membranes damage, gene mutations (below 5\%), oxidative stress, formation of toxic molecules, protein misfolding, and dysfunctional mitochondria (Wider and Wszolek, 2008).

The oxidative stress and cholinergic hypotheses for the onset and development of AD are widely accepted for their relevance to anti-AD drug discovery based on plant-derived natural products (Habtemariam, 2019). As per oxidative stress hypothesis, the accumulation of excessively high levels of free radicals or reactive oxygen species (ROS) in the brain leads to a state of oxidative stress that may have deleterious effects culminating in the neurodegeneration. This is a characteristic feature of Alzheimer's brains. The literature has strong evidence to show the relationship between oxidative attack on the brain and the etiopathology of Alzheimer-related dementia (Huang et al., 2016). As speculated by many research findings, the 
pathological accumulation of free radicals in the brain overburdens the antioxidant defense system of body thereby disturbing the balance between the amount of ROS and available antioxidant reserves which, in turn, is profoundly detrimental to the brain. It may result in the formation of senile plaques in the brains of Alzheimer patients leading to dementia (Abdel Moneim, 2015; Wojsiat et al., 2018). On the other hand, cholinergic hypothesis deals with the disturbance in neurochemical homeostasis resulting in a persistent decline in cholinergic neurotransmission. The impairment of cognitive functions in $\mathrm{AD}$ has been shown to occur as a result of cholinergic deficit and subsequently decreasing levels of a neurotransmitter, the acetylcholine (ACh), in the brain due to its enzymatic hydrolysis by cholinesterases which is linked to amyloid plaques (Hampel et al., 2018; Sultzer, 2018). These findings suggest a putative role of oxidative stress and cholinergic deficit in the development, progression and chronicity of $\mathrm{AD}$ and their importance in defining anti-AD therapeutic goals.

The scientific community is actively engaged in the characterization of plant-derived therapeutic agents for the treatment of $\mathrm{AD}$ for which there are promising results in the literature (Sarris et al., 2011; Kumar and Khanum, 2012; Naaz et al., 2013; Yusoff et al., 2014; Zainol Abidin et al., 2020). Centella asiatica (L.) Urb (C. asiatica) is one of the important medicinal plants used by traditional system of medicine for the treatment of a diverse range of health problems including cognitive disorders (Cheng and Koo, 2000; Hamid et al., 2002; Subathra et al., 2005; Jamil et al., 2007; Pittella et al., 2009; Saha et al., 2013). In addition, C. asiatica has been shown to have antioxidant and anti-acetylcholinesterase (anti-AChE) properties (Jamil et al., 2007). This review attempts to summarize the research findings up to date related to the therapeutic potential of $C$. asiatica for the treatment of $\mathrm{AD}$ specifically for its antioxidant and anti$\mathrm{AChE}$ activities. In this review, we have discussed the etiopathology of $\mathrm{AD}$ followed by a detailed account on $C$. asiatica describing the research findings to date related to its medicinal properties, particularly the antioxidant and anti-AChE activities. The potential therapeutic application of $C$. asiatica for the treatment of $\mathrm{AD}$ including the future prospects has also been discussed.

\section{Alzheimer's brain: the neurochemical aspects}

The brain is made of billions of nerve cells, the neurons, which act as structural and functional units of the nervous system. All the activities of the nervous system are conferred to the health and integrity of these fundamental brain units. Alzheimer's brains present a complex state which may be a combination of neurodegeneration, cholinergic deficit, characteristic neuronal $A \beta$ plaques, and neurofibrillary tangles of tau protein (Sadigh-Eteghad et al., 2015). A review has indicated that vascular abnormalities may lead to the neurodegeneration in AD (Zlokovic, 2011). Irrespective of the causative factors, cholinergic deficit and the oxidative stress appear to be the hallmarks of Alzheimer's brains (Francis et al., 1999; Zhao and Zhao, 2013). A decline in cholinergic neurotransmission has been proposed due to the degenerative cholinergic neurons in basal forebrain resulting in the cognitive decline in AD patients (Mann, 1996). Cholinergic neurotransmission involves acetylcholine, a neurotransmitter. In this context, the research evidence suggests that cholinergic deficit is related to either the reduced activity of enzymes involved in the synthesis of ACh or the hyperactivity of AChE (Sims et al., 1983; DeKosky et al., 1992). AChE is not only involved in the excessive breakdown of $\mathrm{ACh}$, but it also contributes to the formation of Alzheimer's fibrils by increasing the process of assembly of amyloid peptides (Inestrosa et al., 1996) besides increasing their neurotoxicity by making stable complexes with A $\beta$ (Alvarez et al., 1998).

In addition to the cholinergic impairment, oxidative stress is also another important factor for the onset and progression of AD (Padurariu et al., 2013; Zhao and Zhao, 2013). Oxidative stress arises when there is an insufficiency of physiological antioxidant defense system to combat with the accumulated free radicals or reactive oxygen species (ROS) in the body. Although ROS may originate from exogenous factors like tobacco smoking, radiations, etc., most of the ROS are intracellular products of normal physiological working of the body (Phaniendra et al., 2015). Free radicals have the ability to interact with almost all types of biological molecules and may disrupt their normal functions with adverse effects on cellular machinery (Nimse and Pal, 2015). Susceptibility of different body tissues to oxidative damage is variable but brain tissue is considered as more vulnerable to oxidative stress on account of being rich in lipid content and high rate of oxidative metabolism (Cobley et al., 2018). Elevated levels of ROS in AD are attributed to defects in the mitochondrial electron transport chain and extracellular $\mathrm{A} \beta$ deposition which leads to localized inflammation and microglial activation both acting as potential sources of ROS (Guo et al., 2013; Tönnies and Trushina, 2017). Linked to $\mathrm{AD}$, model mice experiments have shown high oxidative stress and increased deposition of $A \beta$ in response to a defective antioxidant defense system (Tönnies and Trushina, 2017; Martins et al., 2018). The fibrillar pathogenesis, one of the hallmarks of $\mathrm{AD}$, is also linked with a relatively high rate of fatty acids oxidation 
which acts as a facilitator for the hyperphosphorylation and polymerization of tau protein (Butterfield and BoydKimball, 2018). Also, the accumulation of a complex of peroxidized lipid and protein, the lipofuscin, has been found in neurons of Alzheimer's brains (Perry et al., 2002).

\section{Centella asiatica}

\subsection{Geographical and botanical description}

Centella asiatica (L.) Urban (syn. Hydrocotyle asiatica L.) belongs to the family Apiaceae (Umbelliferae) (Table 1), known by many names such as "gotu kola, Indian pennywort, Asiatic pennywort, tiger herb, mandukaparni, brahmi", is a tropical, herbaceous plant belonging to the family Apiaceae and native to low, wet swampy areas of Southeast Asia including Malaysia, Indonesia, Sri Lanka, China, India and also found in Africa, Australia and Madagascar. In view of its great medicinal significance, it is specially cultivated in some areas of the world like India, Africa, and Turkey (James and Dubery, 2009; Shinomol and Ravikumar, 2010; Orhan, 2012).

Table 1. Taxonomy of C. asiatica

\begin{tabular}{cc}
\hline Kingdom & Plantae \\
\hline Division & Tracheophyta \\
Subdivision & Spermatophyta \\
Class & Magnoliopsida \\
Order & Apiales \\
Family & Apiaceae (Umbelliferea) \\
Genus & Centella \\
Species & Centella asiatica \\
\hline
\end{tabular}

The plant is greenish in color with a greyish tinge, having a characteristic smell and sweet but slightly bitter in taste. The plant body is herbaceous, slender, creeping, nodular rooting with $1.3-6.3 \mathrm{~cm}$ in diameter leaves having 2-5 cm long leaf stalks without pedicel and contains an umbel type inflorescence having 1-5 flowers which are reddish and sessile. The plant contains $0.8 \mathrm{~cm}$ long, small, but compressed fruit with rectangular mericarps, thick pericarp and laterally compressed seeds (Vohra et al., 2011; Chandrika and Kumara, 2015).

\subsection{Phytochemical constituents}

C. asiatica is known to contain a wide variety of phytochemicals, the secondary metabolites, which signifies the tremendous medicinal importance of this ancient herb. It has been reported to contain the phytochemicals including triterpenoids or saponins, volatile and fatty acids, glycosides, flavonoids, alkaloids, and certain vitamins and free amino acids (Jamil et al., 2007; Latif et al., 2019; Orhan, 2012). A concise summary of the important phytochemical constituents of
C. asiatica has been presented in Table 2 along with representative examples of each main group of $C$. asiatica phytochemicals.

\subsection{Medicinal importance of Centella asiatica - an overview}

C. asiatica is well supported for its medicinal importance in a range of health problems due to its diverse biological actions and is claimed to be successfully practiced in Ayurvedic and Traditional Chinese Systems of Medicine for centuries for a number of medical problems including the cognitive disorders (Gohil et al., 2010; Orhan, 2012). Many research reports have indicated that the alkaloids and flavonoids present in different extracts of $C$. asiatica possess antimicrobial activity against a range of pathogenic microbes (Brinkhaus et al., 2000; Zaidan et al., 2005; Ullah et al., 2009; Yasurin et al., 2016; Jayaprakash and Nagarajan, 2016; Aftab et al., 2017; Idris and Nadzir, 2017; Viera et al., 2017; Prakash et al., 2017; Mahalik et al., 2019; Selvam et al., 2019). Different $C$. asiatica extracts have been found medicinally effective as gastroprotective against cold-induced, stress-induced, ethanol-induced and acetic acid-induced gastric ulcers in rats (Chatterjee et al., 1992; Cheng and Koo, 2000; Sairam et al., 2001; Cheng et al., 2004; Jamil et al., 2007). Many studies have suggested the hepatoprotective role of $C$. asiatica in vitro as well as in vivo (Lin et al., 2002; Antony et al., 2006; Pingale, 2008; Hussin et al., 2014). There are multiple research reports claiming the efficacy of $C$. asiatica as an anti-inflammatory agent by virtue of its diverse range of bioactive compounds (George and Joseph, 2009; Nhiem et al., 2011; Saha et al., 2013; Wan et al., 2013). Anti-tumor and cytotoxic activities have also been reported for C. asiatica (Babu et al., 1995; Bunpo et al., 2004; Babykutty et al., 2009; Pittella et al., 2009; Ullah et al., 2009).

The topical application of C. asiatica has been found efficacious for the treatment of skin ageing in addition to its beneficial role in wound healing (Shetty et al., 2006; Haftek et al., 2008; Kim et al., 2011; Kwon et al., 2012; Ruszymah et al., 2012; Bylka et al., 2014). The methanolic fraction of $C$. asiatica has proved its efficacy for wound healing in vitro as well as in vivo (Azis et al., 2017). Triterpenoid saponins of $C$. asiatica showed immunomodulatory function while aqueous, methanolic, ethanolic and dichloromethane extracts of $C$. asiatica exhibited enhancement of immune function as depicted by various immunity assessment parameters (Jayathirtha and Mishra, 2004; Punturee et al., 2005; Wang et al., 2005; Pan et al., 2010). These studies indicate the therapeutic potential of various extracts of $C$. asiatica for the management and treatment of different ailments. 
Table 2. Phytochemical constituents of $C$. asiatica

\begin{tabular}{|c|c|c|}
\hline Phytochemical Group & Representative Compounds & Reference \\
\hline Alkaloid & Hydrocotylin & (Jamil et al., 2007) \\
\hline \multirow{4}{*}{ Carotenoids } & $\beta$-carotene & \multirow{4}{*}{ (Chandrika and Kumara, 2015) } \\
\hline & Neoxanthei & \\
\hline & Violaxanthin & \\
\hline & Leutein & \\
\hline \multirow{6}{*}{ Fatty Acid Glycerides } & Palmitic acid & \multirow{6}{*}{ (Jamil et al., 2007) } \\
\hline & Stearic acid & \\
\hline & Lignoceric acid & \\
\hline & Oleic acid & \\
\hline & Linoleic acid & \\
\hline & Linolenic acid & \\
\hline \multirow{12}{*}{ Flavonoids } & 3-glucosylquercetin & \multirow{12}{*}{$\begin{array}{l}\text { (Miean and Mohamed, 2001; Vohra et al., 2011; } \\
\text { Roy et al., 2013; Gray et al., 2018) }\end{array}$} \\
\hline & 3-glucosylkaempferol & \\
\hline & 7-glucosylkaempferol & \\
\hline & Catechin & \\
\hline & Epicatechin & \\
\hline & Castilliferol & \\
\hline & Castillicetin & \\
\hline & Apigenin & \\
\hline & Quercetin & \\
\hline & Rutin & \\
\hline & Luteolin & \\
\hline & Naringin & \\
\hline \multirow{9}{*}{ Minerals } & Calcium & \multirow{9}{*}{ (Chong et al., 2011; Chandrika and Kumara, 2015) } \\
\hline & Phosphrus & \\
\hline & Iron & \\
\hline & Magnesium & \\
\hline & Manganese & \\
\hline & Potassium & \\
\hline & Copper & \\
\hline & Zinc & \\
\hline & Sodium & \\
\hline \multirow{4}{*}{ Phenylpropanoids } & Rosemarinic acid & \multirow{4}{*}{ (Chong et al., 2011) } \\
\hline & Chlorogenic acid & \\
\hline & Isochlorogenic acid & \\
\hline & Caffeoyl quinic acids & \\
\hline \multirow{7}{*}{ Saponin Glycosides } & Asiaticosides & \multirow{7}{*}{ (Jamil et al., 2007; Siddiqui et al., 2007) } \\
\hline & Brahminoside & \\
\hline & Brahmosides & \\
\hline & Centellosides & \\
\hline & Centellin & \\
\hline & Cenetillicin & \\
\hline & Madecassosides & \\
\hline \multirow{2}{*}{ Tannins } & Tannin & \multirow{2}{*}{ (Chong et al., 2011) } \\
\hline & Phlobatannin & \\
\hline
\end{tabular}


Table 2 (Cont.). Phytochemical constituents of $C$. asiatica

\begin{tabular}{|c|c|c|}
\hline Phytochemical Group & Representative Compounds & Reference \\
\hline \multirow{14}{*}{ Terpenoids } & Asiatic acid & \multirow{14}{*}{$\begin{array}{l}\text { (Singh and Rastogi, 1969; Aziz et al., 2007; Sid- } \\
\text { diqui et al., 2007; Akula and Odhav, 2008; Hashim } \\
\text { et al., 2011) }\end{array}$} \\
\hline & Asiaticin & \\
\hline & Brahmic acid & \\
\hline & Brahminoside & \\
\hline & Madecassic acid & \\
\hline & Thankuniside & \\
\hline & Sesquiterpenes: & \\
\hline & $\alpha$-Humulene, & \\
\hline & $\beta$-caryophyllene, & \\
\hline & bicyclygermacrene, & \\
\hline & $\begin{array}{c}\text { germacrene B and germacrene } \\
\text { D }\end{array}$ & \\
\hline & Monoterpenes: & \\
\hline & myrcene, & \\
\hline & $\gamma$-terpinene and $\alpha$-pinene & \\
\hline \multirow{7}{*}{ Vitamins } & Ascorbic acid & \multirow{7}{*}{ (Chong et al., 2011, Chandrika and Kumara, 2015) } \\
\hline & Nicotinic acid & \\
\hline & $\beta$-carotene & \\
\hline & Vitamin A & \\
\hline & Thiamine & \\
\hline & Riboflavin & \\
\hline & Niacin & \\
\hline \multirow{12}{*}{ Miscellaneous } & Phytosterols & \multirow{12}{*}{$\begin{array}{l}\text { (Akula and Odhav, 2008; Chong et al., 2011; Roy } \\
\text { et al., 2013; Chandrika and Kumara, 2015) }\end{array}$} \\
\hline & Resin & \\
\hline & Vallerine & \\
\hline & Limonene & \\
\hline & Menthone & \\
\hline & Bornyl acetate & \\
\hline & $\alpha$-elemene & \\
\hline & $\beta$-elemene & \\
\hline & $\gamma$-curcumene & \\
\hline & Spauthulenol & \\
\hline & Caryophyllene oxide & \\
\hline & Mintsulfide & \\
\hline
\end{tabular}

The animal studies on rats and rabbits have investigated the cardioprotective effect of $C$. asiatica for the treatment of experimentally induced cardiac pathological conditions (Pragada et al., 2004; Li et al., 2007; Bian et al., 2008). A number of research findings have signified the medicinal importance of $C$. asiatica in the treatment of diabetes and related diabetic complications (Rao and Mastan, 2007; Ramachandran and Saravanan, 2013; Alqahtani et al., 2013; Kabir et al., 2014; Supkamonseni et al., 2014). The radioprotective function of $C$. asiatica against $\gamma$ - and UVB-irradiation of experimental animals has also been investigated and proved to be efficacious in radiation-induced damage (Shobi and Goel, 2001; Sharma and Sharma, 2002; Sharma and Sharma, 2005; An et al., 2012; Joy and Nair, 2009). A study investigated the anabolic potential of $C$. asiatica and found significant effects as indicated by an overall increase in hemoglobin, blood protein nitrogen and an associated decrease in the mean value of blood urea levels (Jamil et al., 2007). Antiprotozoal, antifilarial, antiviral, antiallergic, antipruritic, antifertility, antitubercular and antispasmodic effects of C. asiatica have also been reported in the literature (Zaidan et al., 2005; Ullah et al., 2009).

A diverse range of various therapeutic effects on nervous system and related ailments has been reported in literature for $C$. asiatica as anticonvulsant, antidepressant, antiepileptic, anxiolytic, tranquilizing, sedative and neuroprotective (Jamil et al., 2007; Kumar et al., 2009; Gohil et al., 2010; Visweswari et al., 2010; Orhan, 2012; Mathew and Subramanian, 2014). In terms 
of the neuroprotective role of $C$. asiatica, its functional properties related to $\mathrm{AO}$ and anti-AChE activities have been a promising area of research specially related to their role in ameliorating the symptoms related to neurodegenerative disorders like AD. The following part of the review will exclusively discuss the therapeutic potential of $C$. asiatica in terms of its antioxidant and anti-AChE activities as has been reported in the literature.

\subsection{Potential anti-AD therapeutic activity}

There are numerous research reports in the scientific literature that show the neuroprotective effects of $C$. asiatica and emphasize its immense potential as a candidate for anti-AD therapeutic agent (Brinkhaus et al., 2000; Gohil et al., 2010; Vohra et al., 2011). As mentioned earlier, oxidative stress and cholinergic deficit are major factors related to $\mathrm{AD}$ pathology so $C$. asiatica will be reviewed in connection to the antioxidant and anti-AChE activities reported in the literature.

\section{Antioxidant activity of $C$. asiatica extracts}

$C$. asiatica has tremendous potential of being a natural source of antioxidant as its antioxidant activity has been found comparable to that of Rosemary and sage (Jamil et al., 2007). Protective role of $C$. asiatica extract against $\gamma$-radiation induced DNA damage in vitro has been revealed by plasmid relaxation assay and the radioprotective function of $C$. asiatica has been suggested to its antioxidant property (Joy and Nair, 2009). In a comparative study involving 43 edible plants of Thailand, $C$. asiatica showed a comparatively high level of natural antioxidant compounds including vitamin $\mathrm{C}$, vitamin $\mathrm{E}$, carotenes, tannins and total phenolics (Chanwitheesuk et al., 2005).

The leaves of $C$. asiatica have been tested in vitro for superoxide free radical activity, inhibition of linoleic acid peroxidation, and 2,2-diphenyl-1-picryl-hydrazyl (DPPH) radical scavenging activity and appeared to possess high antioxidant potential (Shukla et al., 2012) which correlate with the findings that $C$. asiatica leaves possess a higher level of natural antioxidant (Odhav et al., 2007; Akula and Odhav, 2008). Zainol et al. (2003) performed a comparative study to investigate the antioxidant activity of extracts from different parts of $C$. asiatica and the highest antioxidant activity was found in $C$. asiatica leaf extract. Their finding positively correlated with the phenolic contents of $C$. asiatica leaves which were found to have the highest phenolic content as compared to the other parts of $C$. asiatica. The results of this study suggested that phenolics might be the most potent bioactive compounds in terms of $C$. asiatica antioxidant activity. Contrary to this study, root extract showed the maximum antioxidant activity irrespective of the type of solvent used in a study that determined the antioxidant potential of $C$. asiatica in extracts from different plant parts including root, petiole and leaf. In particular, the ethanolic extracts of root and leaf showed antioxidant activity fairly comparable to $\alpha$ tocopherol (Hamid et al., 2002).

The statistically significant values of free radical scavenging activity in ethanolic extracts of $C$. asiatica leaves were found attributable to polyphenols and flavonoids as the plant secondary metabolites are likely to be more concentrated in this fraction. Also, the methanolic extract of $C$. asiatica leaves was found to have DNA damage protective activity (Anand et al., 2010) and the finding is interesting in view of the concept that the accumulation of free radicals may lead to DNA damage and ageing, the risk factors for the onset and development of Alzheimer's disease.

The free radical scavenging activity of the aqueous extract of $C$. asiatica with an $\mathrm{IC}_{50}$ value of $31.25 \mu \mathrm{g} / \mathrm{mL}$ was found statistically significant against the $\mathrm{IC}_{50}$ values of $2.50 \mu \mathrm{g} / \mathrm{mL}$ and $7.58 \mu \mathrm{g} / \mathrm{mL}$ generated by ascorbic acid and butylated hydroxytoluene (BHT), respectively. The significantly high antioxidant activity of $C$. asiatica aqueous extract was hypothesized to the flavonoids (Pittella et al., 2009) on account of having numerous hydroxyl groups, the hydrogen-donors, best suited to possess powerful free radical scavenging activity (Cao et al., 1997; Mensor et al., 2001). Ferric thiocyanate (FTC) test and thiobarbituric acid (TBA) test were used to find the antioxidant activity in aqueous extracts of six Malaysian herbs including $C$. asiatica and the highest antioxidant activity was shown by $C$. asiatica extract in TBA test (Huda-Faujan et al., 2007).

\subsection{Centella asiatica antioxidant activity: animal studies}

As insufficiency of body's AO defence mechanism is considered as a hallmark of $\mathrm{AD}$, an experimental mice model study elucidated the association of sporadic AD in humans with intracerebroventricular (ICV) streptozotocin (STZ) in rats and the production of free radicals with the cognitive impairment in this model. The cognitive dysfunction and oxidative stress were induced in male Wistar rats after bilaterally injecting ICV STZ (3 $\mathrm{mg} / \mathrm{kg}$ ) on days one and three followed by evaluation of therapeutic effects of $C$. asiatica aqueous extract for twenty-one days. After that, the behavioural task was completed and rats were killed to assess the level of oxidative stress in the whole brain. Interestingly, there was a dose-dependent improvement in cognition level as well as an increase in free radical scavengers in $C$. asiatica treated rats (Veerendra Kumar and Gupta, 2003). 
The oral administration of $50 \mathrm{mg} / \mathrm{kg} /$ day crude methanolic extract of $C$. asiatica to a lymphoma-bearing mouse resulted in a significant increase in antioxidant enzymatic activity notably of superoxide dismutase (SOD), catalase (CAT) and glutathione peroxidase (GSHPx) (Jayashree et al., 2003). Therapeutic effect of $C$. asiatica as antioxidant was studied on administering the $C$. asiatica extract (300 $\mathrm{mg} / \mathrm{kg}$ body weight/day) for a period of 60 days by monitoring lipid peroxidation (LPO) and protein carbonyl (PCO) contents in selected five anatomical parts of aged rat brains viz. cortex, hypothalamus, striatum, cerebellum and hippocampus having low antioxidant status and high LPO and PCO contents in all five regions of brain compared to the control rats. The treatment with $C$. asiatica extract was found to be efficacious in decreasing LPO and PCO contents in regional brain areas with a relative increase in antioxidant level (Subathra et al., 2005).

The alleviation of oxidative stress in SpragueDawley female rats pre-treated with monosodium glutamate was observed on administration of $C$. asiatica extract (100 and $200 \mathrm{mg} / \mathrm{kg}$ body weight) by monitoring SOD and CAT levels which showed a post-treatment increase while glutathione levels were unaffected (Hussin et al., 2007). CV colchicine $(15 \mu \mathrm{g} / 5 \mu \mathrm{L})$ was injected to male Wistar rats that produced a profound impairment to their memory and antioxidant level. Starting four days before colchicine treatment, administration of $C$. asiatica extract (150 and $300 \mathrm{mg} /$ $\mathrm{kg}$ ) spanning over twenty-five days resulted in a significant decrease in memory impairment and oxidative damage induced by colchicine (Kumar et al., 2009). The same researchers investigated the role of $C$. asiatica as potent antioxidant in mice model with memory impairment and oxidative damage induced by a chronic administration of D-galactose $(100 \mathrm{mg} / \mathrm{kg})$ to mice over six weeks followed by $C$. asiatica treatment (150 and $300 \mathrm{mg} / \mathrm{kg}$ ) for six weeks that had a significantly protective effect as shown by cognitive improvement and reversal of oxidative damage compared to control (Kumar et al., 2011).

Male Wistar rats were kept on aluminium $(100 \mathrm{mg} /$ $\mathrm{kg}$ body weight) and C. asiatica (150 and $300 \mathrm{mg} / \mathrm{kg}$ body weight). Centella asiatica proved to have a neuroprotective function as reflected by a significant improvement in mitochondrial dysfunction in the experimental animal as compared to control (Prakash and Kumar, 2013). The aqueous extract of C. asiatica in doses of 200 and $300 \mathrm{mg} / \mathrm{kg}$ was tested for oxidative stress that significantly decreased the malondialdehyde (MDA) levels in the brain with a parallel increase in glutathione levels. At $300 \mathrm{mg} / \mathrm{kg}$, C. asiatica extract was effective in increasing the CAT levels but SOD levels were not significantly increased (Kumar and Gupta, 2002).

The parameters of oxidative stress including LPO, ROS production, hydroperoxide and $\mathrm{PCO}$ synthesis were shown to reduce in four selected brain areas (cortex, cerebellum, hippocampus and striatum) of prepubertal mice on administering the $C$. asiatica leaf powder in contrast to control animals. Also, the mitochondrial and cytosolic parts of various brain regions exhibited an increased antioxidant level in experimental animals on diet supplemented with $C$. asiatica leaf powder. The potent action of $C$. asiatica administration was evident by up-regulation of glutathione reduction, total thiols, non-protein thiols and antioxidant enzymatic activities in the mentioned brain areas (Shinomol, 2008b; Shinomol and Ravikumar, 2010).

The aqueous extract of $C$. asiatica was found to have considerable prophylactic neuroprotective action in animal models kept on C. asiatica prophylaxis $(5 \mathrm{mg} / \mathrm{kg}$ body weight) for 10 days coupled with the injection of 3nitropropionic acid (3-NPA) only for last 2 days (i. p., 75 $\mathrm{mg} / \mathrm{kg}$ body weight/day). A complete attenuation of oxidative stress in brain areas including striatum induced by 3-NPA was observed due to $C$. asiatica prophylaxis in experimental models as compared to the control animals (Shinomol, 2008a).

The effect of $C$. asiatica extract on AD pathology related to $A \beta$ plaque formation in a double transgenic mouse carrying presenilin 1/amyloid precursor protein (PSAPP) mutations were studied and positive therapeutic effects of $C$. asiatica extract were confirmed by observing a decline in $A \beta$ and fibrillar amyloid plaques on treatment with $C$. asiatica extract at $2.5 \mathrm{mg} / \mathrm{kg}$ body weight and $5 \mathrm{mg} / \mathrm{kg}$ body weight, respectively. Additionally, the antioxidant function was also confirmed in vitro (Dhanasekaran et al., 2009).

A pentacyclic triterpene of $C$. asiatica, the asiatic acid (AA), has been found to restore the parameters related to oxidative stress to the normal values in hippocampus and cortical regions of rat brains with monosodium glutamate (MSG) induced oxidative stress as revealed by quantifying the amounts of lipid peroxidation, superoxide dismutase and glutathione $(\mathrm{Xu}$ et al., 2012).

The hamster model with hyperlipidemia induced by high-fat diet (HFD) was used in an investigation to explore the antioxidant potential of $C$. asiatica ethanolic extract in vivo. The antioxidant activities of SOD and GSHPx were found to increase while that of MDA was significantly decreased in hyperlipidemic golden hamsters after 35 days' treatment with $95 \%$ ethanolic 
extract of C. asiatica (Zhao et al., 2014).

An investigation has shown the radioprotective property of $C$. asiatica extract in case of whole-body exposure to $\gamma$-radiations as assessed by the experiment on mouse bone marrow cells using an alkaline comet assay (Joy and Nair, 2009). The oxidative stress was induced in experimental rats by administering $20 \mathrm{ppm}$ arsenic (III) for 4 weeks in drinking water coupled with C. asiatica supplementation and there was a significant increase in the level of brain thiobarbituric acid reactive substance (TBARS) (Gupta and Flora, 2006) supported by another study on the effect of $C$. asiatica extract on arsenic-induced oxidative stress in experimental rats (Flora and Gupta, 2007).

\section{Cognitive effects of Centella asiatica extract: studies on mouse models}

Multiple studies on rodents have evaluated the cognitive effects of $C$. asiatica water extracts and shown their efficacy on improvement in cognition level of experimental animal models as assessed by standard behavioral tests. Mouse models with MSG induced dementia were produced to investigate the role of antioxidant activity by giving subcutaneous injection of MSG in the neck $(2.5 \mathrm{mg} / \mathrm{g}$ body weight $)$ to neonatal mice (the experimental group) from $7^{\text {th }}$ to $13^{\text {th }}$ postnatal days while the control group was administered with only $0.9 \%$ sodium chloride $(\mathrm{NaCl})$. On $28^{\text {th }}$ postnatal day, the animals of the same gender receiving the same treatment were grouped together. From $14^{\text {th }}$ to $30^{\text {th }}$ postnatal days, oral treatment with antioxidant activity $(50 \mathrm{mg} / \mathrm{kg}$ and $100 \mathrm{mg} / \mathrm{kg}$ body weight) was given to the drug group followed by the assessment of cognition level through standard behavioral test in which the animals receiving high dose of antioxidant activity showed significantly better performance compared to the control (Xu et al., 2012). Neonatal mice showed efficient learning and improvement in dimensional memory when treated with C. asiatica water extract from $15^{\text {th }}$ to $30^{\text {th }}$ postpartum days (Rao et al., 2005).

The cognitive effects of $C$. asiatica water extract were studied in the most popular transgenic animal model for AD, Tg2576 mouse, in which age and spacedependent $\mathrm{AD}$ pathology were produced by inserting a mutant human APP gene into its genome. Following $C$. asiatica extract treatment, the experimental animal model showed improvements in AD-associated behavioral deficits (Soumyanath et al., 2012). In continuation to it, researchers investigated for the bioactive compound of $C$. asiatica extract and confirmed several mono- and dicaffeoylquinic acids (CQAs) in $C$. asiatica extract with neuroprotective properties as assessed and evaluated in MC65 and SH-SY5Y, the neuroblastoma cell lines (Gray et al., 2014) supported by a previous study that showed the neuroprotective effect of dicaffeoylquinic acids against A $\beta$-induced neurotoxicity in SH-SY5Y (Deng et al., 2013).

\section{Cell culture assays: the molecular insight of Centella asiatica medicinal potential}

The neuroprotective role of $C$. asiatica was investigated on human neuroblastoma cells SH-SY5Y pretreated with antioxidant activity $(0.1-100 \mathrm{nmol} / \mathrm{L})$ that resulted in attenuation of glutamate-induced $(10 \mathrm{nmol} / \mathrm{L})$ toxicity with a promoting effect on upregulation of peroxisome proliferator-activated receptor-gamma coactivator-1 $\alpha$ (PGC-1 $\alpha)$ and silent information regulator 2 family of protein 1 (Sirt1) (Xu et al., 2012). In order to elucidate the underlying molecular signaling pathway involved in neuroprotective effect of $C$. asiatica, a standardized C. asiatica extract (Eca 233) (Wanasuntronwong et al., 2012) was used at the dose of $1-100 \mu \mathrm{g} / \mathrm{ml}$ in a study on IMR-32 neuroblastoma cells which caused the hyperphosphorylation of ERK and Akt proteins reflecting their activation under Eca 233. In addition, the role of ERK/Akt signaling pathway was later confirmed by using specific inhibitors of MEK or P13K that abrogated the nuritogenic effect of Eca 233 suggesting its nuritogenic property based on MEK/ERK and P13K/Akt signaling pathways in human neuroblastoma IMR-32 cells (Wanakhachornkrai et al., 2013).

Another study on $A \beta$ expressing neuroblastoma cells linked the memory-enhancing property of $C$. asiatica extract with the involvement of ERK/RSK signaling pathway as a plausible molecular array (Xu et al., 2008). In a recent study based on cell culture assays, the researchers found that aqueous extract of $C$. asiatica profoundly decreased the level of ROS in cells having A $\beta$-induced oxidative stress. They also reported $C$. asiatica aqueous extract-induced expression of antioxidant response gene NEF2L2 in MC65 and SHSY5Y neuroblastoma cells. There was a significant increase in mitochondrial electron transport chain genes expression in primary neurons of rat hippocampus with a parallel induction in antioxidant response gene expression in primary neurons as well (Gray et al., 2015).

\section{Antiacetylcholinesterase activity of Centella asiatica}

The ACh has a neuromodulatory effect in the brain and acts as a neurotransmitter for cholinergic synaptic transmission. The enzyme AChE belongs to the family 
of cholinesterases that are special carboxyl ester hydrolases. Activation of postsynaptic ACh receptors is followed by the $\mathrm{AChE}$ catalyzed hydrolytic cleavage of the ester bond in ACh into choline and acetate, the event which eventually terminates the cholinergic nerve transmission governed by ACh (Barbosa Filho et al., 2006; Lionetto et al., 2013).

As proposed by the cholinergic hypothesis, the abnormally high activity of AChE results in a decline in ACh concentration in the brain leading to a state of cholinergic deficit that contributes to the development and progression of $\mathrm{AD}$. In view of its pathological role, $\mathrm{AChE}$ has become a promising target in drug discovery research to find its natural inhibitors. In the following account, an attempt has been made to give a comprehensive view of the importance of $C$. asiatica as a promising candidate to investigate for the novel, natural anti-AChE based on the research findings in the literature.

The cell culture assay has shown an up-regulation of AChE expression in cultured embryonal carcinoma P19 cells in response to $\mathrm{A} \beta$ peptide accumulation (Sberna et al., 1997). AChE is considered as the target enzyme for the treatment of $\mathrm{AD}$ by virtue of its hydrolytic action on ACh leading to a decline in ACh level in AD brains (Orhan et al., 2006). The ethanolic extract of C. asiatica was tested for anti-AChE activity in-vitro and the results confirmed that it possessed a significant level of antiAChE activity (Rahman et al., 2012). An in-vitro study was carried out in which six traditional herbs commonly practiced in Indian system of medicine were tested for anti-AChE activity. This study revealed that at $100-$ $150 \mu \mathrm{g} / \mathrm{mL}$ concentration, the hydroalcoholic extract of CA has shown a $50 \%$ inhibition of AChE compared to standard physostigmine's $\mathrm{IC}_{50}$ value of $0.076 \pm 0.0042 \mu \mathrm{g} /$ $\mathrm{mL}$ (Mukherjee et al., 2007).

In a comparative study on ethanolic extracts of aerial parts of C. asiatica of Turkey and India together with a standard $C$. asiatica extract of Chinese origin, only the standard C. asiatica extract at a concentration of $200 \mu \mathrm{g} /$ $\mathrm{mL}$ showed $48.28 \pm 1.64 \%$ inhibition of AChE (Orhan et al., 2013). In another comparative study involving twenty different medicinal plants, traditionally used in Ayurvedic system of medicine for memory problems, were tested for their AChE inhibitory activity. The study resulted in the $\mathrm{IC}_{50}$ value of $890 \pm 67.4$ in $\mathrm{AChE}$ inhibition assay for the methanolic extract of $C$. asiatica (Mathew and Subramanian, 2014).

In an in-vitro study on six selected Malaysian plant extracts for AChE inhibitory potential, C. asiatica extracts from leaves and roots were tested and consequently, the leaf extract showed high $\mathrm{AChE}$ inhibitory activity compared to the extract of the roots (Nour et al., 2014). An in-vitro study has investigated the AChE inhibitory activity of asiatic acid which is a triterpenoid isolated from $C$. asiatica in context to its role in learning and memory enhancement. TLC bioautographic AChE inhibitory assay was performed to test the AChE inhibitory potential of asiatic acid in which a two-fold serial dilution of asiatic acid showed an anti-AChE property at the concentration of $125 \mathrm{ng}$ compared with the AChE inhibition by physostigmine and galanthamine at the concentration of $1 \mathrm{ng}$ and $10 \mathrm{ng}$, respectively (Nasir et al., 2012).

The anticonvulsant property of different $C$. asiatica extracts relative to cholinergic property was studied in rats with pentylenetetrazole (PTZ)-induced seizures. The rats were kept on oral treatment with different aqueous extracts of CA at a dose of $200 \mathrm{mg} / \mathrm{kg}$ body weight for one week followed by PTZ treatment to induce seizures. Different brain regions of seized rats showed increased ACh level and decreased AChE activity during the period of PTZ-induced seizures as compared to the control group (Visweswari et al., 2010).

An experiment revealed that ICV administration of colchicine at a dose of $15 \mu \mathrm{g} / 5 \mu \mathrm{L}$ injection volume resulted in significantly high level of AChE activity in the brain of male Wistar rats. However, chronic oral treatment of ICV-colchicine treated rats with aqueous $C$. asiatica extract $(150 \mathrm{mg} / \mathrm{kg}$ and $300 \mathrm{mg} / \mathrm{kg}$, P.O.) administered as $0.5 \mathrm{~mL} / \mathrm{kg}$ body weight resulted in a significant attenuation of increased AChE activity as compared to the colchicine-treated animals (Kumar et al., 2009).

The whole-brain anti-AChE activity of lyophilized leaf-water extract of C. asiatica was investigated in male albino Wistar rats in which stress was induced by containing the animals in plastic tubes of size $20 \mathrm{~cm} \times 7$ $\mathrm{cm}$ for two hours a day over a period of total twenty-one days. On day 21 , the animals were killed by cervical displacement and whole-brain anti-AChE activity was determined by Ellman's method. The results of this experiment revealed that $\mathrm{AChE}$ activity was significantly higher in stress condition as compared to the control group. On co-administering the stressed animals with lyophilized leaf-extract of CA $(200 \mathrm{mg} / \mathrm{kg}$ bodyweight for 21 days), the AChE activity was observed to be nearly normal. In addition, the stress-free control group did not show any significant change in AChE level on the administration of lyophilized leaf-extract of $C$. asiatica $(200 \mathrm{mg} / \mathrm{kg}$ bodyweight for 21 days) (Sarumathi and Saravanan, 2013). Monoterpenes identified in $0.1 \%$ essential oil extracted from C. asiatica (Brinkhaus et al., 2000) were reported as AChE inhibitors (Miyazawa and 
Yamafuji, 2005).

The role of asiatic acid as anti-AChE inhibitor was investigated in hippocampal cell lines in which the asiatic acid was applied to the cell lines followed by the analyses of AChE activity and probable toxicity of asiatic acid. This study reported asiatic acid as an effective AChE inhibitor without any toxic side effects on hippocampal cell lines (Boopathy et al., 2009). It is, however, worth mentioning that literature does cite a reference showing a significant increase in the level of AChE in Swiss albino mice during postnatal period on $C$. asiatica treatment besides showing a positive nootropic effect of $C$. asiatica as indicated by enhancement in learning and memory functions of the experimental animals (Rao et al., 2005).

\section{Future prospects and conclusion}

The antioxidant therapy has been linked to the suppression of $\mathrm{AD}$-related symptoms by retarding the oxidative damage as shown in mouse models on AD. In view of it, the use of antioxidant as a therapeutically active agent might prove beneficial in devising effective treatment strategies for AD. Anti-AChEs have been shown to be the multifunctional molecules that not only have their direct role in AChE inhibition but also work as free radical detoxifiers and anti-inflammatory agents. These diverse therapeutically important biological functions of anti-AChEs make them a good candidate as part of the AD treatment regimen. Also, a huge body of research data suggests the promising nature of drug discovery related to $\mathrm{AD}$ therapy in context to new antioxidants and anti-AChE from natural sources including plants. To date, the majority of the antioxidants and therapeutically active biomolecules against a number of diseases including cognitive disorders have been identified, isolated and purified from plant sources that exhibit the therapeutic potential of the plant world. In view of its tremendous medicinal importance for a large number of medical problems including nervous system ailments and claimed to be successfully practiced in different traditional systems of medicine across the world since centuries, $C$. asiatica appears to be a good candidate for new drug discovery research in order to search for novel antioxidants and AChE inhibitors. Despite the enormous therapeutic potential of alkaloids for the treatment of $\mathrm{AD}$, it may be concluded that investigative research particularly related to $C$. asiatica alkaloids appears to be the most neglected area of drug discovery.

Alzheimer's disease is a type of neurodegenerative disorders affecting behavioural, social and economic aspects of not only the patients but also the society at large. AD is considered as a multifactorial problem involving the accumulation of high level of free radicals or ROS as well as the cholinergic deficit in AD brains that contribute to its development and progression. A number of research studies emphasize the impact of oxidative stress as one of the key factors in the development and progression of various neurodegenerative disorders including AD. Increasing research evidence indicates that development of $\mathrm{AD}$ is strongly correlated to the exposure of Alzheimer's brains to oxidative stress which represents a disturbance in the delicate balance between the production of ROS and oxidant detoxification mechanism leading to a dysfunctional biological system. In addition, the role of $\mathrm{AChE}$ in cholinergic neurotransmission has been intensively studied in the past several decades highlighting the therapeutically important status of anti$\mathrm{AChE}$ in the treatment of $\mathrm{AD}$. Low levels of $\mathrm{ACh}$ in Alzheimer's brains implicate the need to suppress the activity of $\mathrm{AChE}$ in order to restore the cholinergic neurotransmission and hence the importance of antiAChE becomes evident. Multiple studies have shown the therapeutic potential of anti-AChE for the reduction of AD-related symptoms. Since decades, plants have been the focus of active research as sources of natural antioxidants and other therapeutic molecules and $C$. asiatica is one of the widely used traditional plants with proven efficacy in cognitive disorders as claimed by folk medicine. This review has summarized the research related to the same and concludes that there are many missing links in $C$. asiatica research aiming at anti-AD drug discovery that still needs to be established to elucidate the comprehensive biochemical nature of its therapeutically active biomolecules so as to reach a definite cure for $\mathrm{AD}$.

\section{Conflict of interest}

The authors declare no conflict of interest.

\section{Acknowledgments}

This paper was supported by the office of Research Management Centre (RMC), Universiti Tun Hussein Onn Malaysia (UTHM) through the support with Geran Penyelidikan Pascasiswazah (GPPS) Vot. No. U490 and Research Fund Vot No. E15501, in addition to Fundamental Research Grant Scheme (FRGS) Vot. No. K104 and Research Acculturation Grant Scheme (RAGS) (Vot. No. 050) provided by the Ministry of Higher Education Malaysia.

\section{References}

Abdel Moneim, A.E. (2015). Oxidant/antioxidant imbalance and the risk of Alzheimer's disease. 
Current Alzheimer Research, 12(4), 335-349. https:// doi.org/10.2174/1567205012666150325182702

Aftab, A., Khan, Z.D., Yousaf, Z., Javad, S., Shamsheer, B., Zahoor, M., Riaz, N., Javed, S., Yasin, H. and Ramzan, H. (2017). Exploration of Ethnopharmacological Potential of Antimicrobial, Antioxidant, Anthelmintic and Phytochemical Analysis of Medicinally Important Plant Centella asiatica (L.) Urban in Mart. and Eichl. American Journal of Plant Sciences, 8(2), 201-211. https:// doi.org/10.4236/ajps.2017.82016

Akula, U.S. and Odhav, B. (2008). In vitro 5lipoxygenase inhibition of polyphenolic antioxidants from undomesticated plants of South Africa. Journal of Medicinal Plants Research, 2(9), 207-212.

Alqahtani, A., Hamid, K., Kam, A., Wong, K., Abdelhak, Z., Razmovski-Naumovski, V., Chan, K., Li, K.M., Groundwater, P.W. and Li, G.Q. (2013). The pentacyclic triterpenoids in herbal medicines and their pharmacological activities in diabetes and diabetic complications. Current Medicinal Chemistry, 20(7), 908-931. https:// doi.org/10.2174/092986713805219082

An, I.-S., An, S., Kang, S.-M., Choe, T.-B., Lee, S.N., Jang, H. H. and Bae, S. (2012). Titrated extract of Centella asiatica provides a UVB protective effect by altering microRNA expression profiles in human dermal fibroblasts. International Journal of Molecular Medicine, 30(5), 1194-1202. https:// doi.org/10.3892/ijmm.2012.1117

Anand, T., Mahadeva, N., Phani, K.G. and Farhath, K. (2010). Antioxidant and DNA Damage Preventive Properties of Centella asiatica (L) Urb. Pharmacognosy Journal, 2(17), 53-58. https:// doi.org/10.1016/S0975-3575(10)80010-0

Antony, B., Santhakumari, G., Merina, B., Sheeba, V. and Mukkadan, J. (2006). Hepatoprotective effect of Centella asiatica $(\mathrm{L})$ in carbon tetrachloride-induced liver injury in rats. Indian Journal of Pharmaceutical Sciences, 68(6), 772-776. https:// doi.org/10.4103/0250-474X.31013

Azis, H., Taher, M., Ahmed, A., Sulaiman, W., Susanti, D., Chowdhury, S. and Zakaria, Z. (2017). In vitro and In vivo wound healing studies of methanolic fraction of Centella asiatica extract. South African Journal of Botany, 108, 163-174. https:// doi.org/10.1016/j.sajb.2016.10.022

Aziz, Z., Davey, M., Power, J., Anthony, P., Smith, R. and Lowe, K. (2007). Production of asiaticoside and madecassoside in Centella asiatica in vitro and in vivo. Biologia Plantarum, 51(1), 34-42. https:// doi.org/10.1007/s10535-007-0008-x

Babu, T., Kuttan, G. and Padikkala, J. (1995). Cytotoxic and anti-tumour properties of certain taxa of
Umbelliferae with special reference to Centella asiatica (L.) Urban. Journal of Ethnopharmacology, 48(1), 53-57. https://doi.org/10.1016/0378-8741(95) 01284-K

Babykutty, S., Padikkala, J., Sathiadevan, P., Vijayakurup, V., Azis, T., Srinivas, P. and Gopala, S. (2009). Apoptosis induction of Centella asiatica on human breast cancer cells. African Journal of Traditional, Complementary and Alternative Medicines, 6(1), 9-16. https://doi.org/10.4314/ ajtcam.v6i1.57068

Barbosa Filho, J.M., Medeiros, K.C.P., Diniz, M. d. F.F., Batista, L.M., Athayde-Filho, P.F., Silva, M.S., da Cunha, E.V., Almeida, J.R. and Quintans-Júnior, L.J. (2006). Natural products inhibitors of the enzyme acetylcholinesterase. Revista Brasileira de Farmacognosia, 16(2), 258-285. https:// doi.org/10.1590/S0102-695X2006000200021

Bian, G.-X., Li, G.-G., Yang, Y., Liu, R.-T., Ren, J.-P., Wen, L.-Q., Guo, S.-M. and Lu, Q.-J. (2008). Madecassoside reduces ischemia-reperfusion injury on regional ischemia induced heart infarction in rat. Biological and Pharmaceutical Bulletin, 31(3), 458463. https://doi.org/10.1248/bpb.31.458

Boopathy, R., Chitra, L., Prabha, N.S. and Babu, S.A. (2009). Effect of asiatic acid on hippocampal cell line: A novel inhibitor of acetylcholinesterase from Centella asiatica. Alzheimer's and Dementia: The Journal of the Alzheimer's Association, 5(4), P328P329. https://doi.org/10.1016/j.jalz.2009.04.546

Brinkhaus, B., Lindner, M., Schuppan, D. and Hahn, E. (2000). Chemical, pharmacological and clinical profile of the East Asian medical plant Centella asiatica. Phytomedicine, 7(5), 427-448. https:// doi.org/10.1016/S0944-7113(00)80065-3

Bunpo, P., Kataoka, K., Arimochi, H., Nakayama, H., Kuwahara, T., Bando, Y., Izumi, K., Vinitketkumnuen, U. and Ohnishi, Y. (2004). Inhibitory effects of Centella asiatica on azoxymethane-induced aberrant crypt focus formation and carcinogenesis in the intestines of F344 rats. Food and Chemical Toxicology, 42(12), 1987-1997. https://doi.org/10.1016/j.fct.2004.06.022

Butterfield, D.A. and Boyd-Kimball, D. (2018). Oxidative stress, amyloid- $\beta$ peptide, and altered key molecular pathways in the pathogenesis and progression of Alzheimer's disease. Journal of Alzheimer's Disease, 62(3), 1345-1367. https:// doi.org/10.3233/JAD-170543

Bylka, W., Znajdek-Awiżeń, P., Studzińska-Sroka, E., Dańczak-Pazdrowska, A. and Brzezińska, M. (2014). Centella asiatica in dermatology: an overview. Phytotherapy Research, 28(8), 1117-1124. https:// doi.org/10.3233/JAD-170543 
Cao, G., Sofic, E. and Prior, R.L. (1997). Antioxidant and prooxidant behavior of flavonoids: structureactivity relationships. Free Radical Biology and Medicine, 22(5), 749-760. https://doi.org/10.1016/ S0891-5849(96)00351-6

Chandrika, U.G. and Kumara, P.A.P. (2015). Gotu kola (Centella asiatica): Nutritional properties and plausible health benefits. Advances in Food and Nutrition Research, 76, 125-157. https:// doi.org/10.1016/bs.afnr.2015.08.001

Chanwitheesuk, A., Teerawutgulrag, A. and Rakariyatham, N. (2005). Screening of antioxidant activity and antioxidant compounds of some edible plants of Thailand. Food Chemistry, 92(3), 491-497. https://doi.org/10.1016/j.foodchem.2004.07.035

Chatterjee, T., Chakraborty, A., Pathak, M. and Sengupta, G. (1992). Effects of plant extract Centella asiatica (Linn.) on cold restraint stress ulcer in rats. Indian Journal of Experimental Biology, 30 (10), 889-891.

Chen, X.-Q. and Mobley, W.C. (2019). Alzheimer disease pathogenesis: insights from molecular and cellular biology studies of oligomeric $\mathrm{A} \beta$ and tau species. Frontiers in Neuroscience, 13, 659. https:// doi.org/10.3389/fnins.2019.00659

Cheng, C. and Koo, M. (2000). Effects of Centella asiatica on ethanol induced gastric mucosal lesions in rats. Life Sciences, 67(21), 2647-2653. https:// doi.org/10.1016/S0024-3205(00)00848-1

Cheng, C. L., Guo, J.S., Luk, J. and Koo, M.W.L. (2004). The healing effects of Centella extract and asiaticoside on acetic acid induced gastric ulcers in rats. Life Sciences, 74(18), 2237-2249. https:// doi.org/10.1016/j.lfs.2003.09.055

Chong, N.J., Aziz, Z., Jhala, V. and Thaker, V. (2011). A systematic review on the chemical constituents of Centella asiatica. Research Journal of Pharmaceutical, Biological and Chemical Sciences, 2(3), 445-459.

Cobley, J.N., Fiorello, M.L. and Bailey, D.M. (2018). 13 reasons why the brain is susceptible to oxidative stress. Redox Biology, 15, 490-503. https:// doi.org/10.1016/j.redox.2018.01.008

Deng, J., Qi, X.L., Guan, Z.Z., Yan, X.M., Huang, Y. and Wang, Y.L. (2013). Pretreatment of SH-SY5Y cells with dicaffeoylquinic acids attenuates the reduced expression of nicotinic receptors, elevated level of oxidative stress and enhanced apoptosis caused by $\beta$-amyloid peptide. Journal of Pharmacy and Pharmacology, 65(12), 1736-1744. https:// doi.org/10.1111/jphp.12096

Dhanasekaran, M., Holcomb, L.A., Hitt, A.R., Tharakan, B., Porter, J.W., Young, K.A. and Manyam, B.V. (2009). Centella asiatica extract selectively decreases amyloid $\beta$ levels in hippocampus of Alzheimer's disease animal model. Phytotherapy Research: An International Journal Devoted to Pharmacological and Toxicological Evaluation of Natural Product Derivatives, 23(1), 14-19. https:// doi.org/10.1002/ptr.2405

Flora, S. and Gupta, R. (2007). Beneficial effects of Centella asiatica aqueous extract against arsenicinduced oxidative stress and essential metal status in rats. Phytotherapy Research, 21(10), 980-988. https://doi.org/10.1002/ptr.2208

Franceschi, C., Garagnani, P., Morsiani, C., Conte, M., Santoro, A., Grignolio, A., Monti, D., Capri, M. and Salvioli, S. (2018). The continuum of aging and agerelated diseases: common mechanisms but different rates. Frontiers in Medicine, 5, 61. https:// doi.org/10.3389/fmed.2018.00061

George, M. and Joseph, L. (2009). Anti-allergic, antipruritic, and anti-inflammatory activities of Centella asiatica extracts. African Journal of Traditional, Complementary and Alternative Medicines, 6(4), 554 -559. https://doi.org/10.4314/ajtcam.v6i4.57206

Gohil, K.J., Patel, J.A. and Gajjar, A.K. (2010). Pharmacological review on Centella asiatica: a potential herbal cure-all. Indian Journal of Pharmaceutical Sciences, 72(5), 546-556. https:// doi.org/10.4103/0250-474X.78519

Gray, N.E., Magana, A.A., Lak, P., Wright, K.M., Quinn, J., Stevens, J.F., Maier, C.S. and Soumyanath, A. (2018). Centella asiatica: phytochemistry and mechanisms of neuroprotection and cognitive enhancement. Phytochemistry Reviews, 17(1), 161-194. https://doi.org/10.1007/ s11101-017-9528-y

Gray, N.E., Morré, J., Kelley, J., Maier, C.S., Stevens, J.F., Quinn, J.F. and Soumyanath, A. (2014). Caffeoylquinic acids in Centella asiatica protect against amyloid- $\beta$ toxicity. Journal of Alzheimer's Disease, 40(2), 359-373. https://doi.org/10.3233/ JAD-131913

Gray, N.E., Sampath, H., Zweig, J.A., Quinn, J.F. and Soumyanath, A. (2015). Centella asiatica attenuates amyloid- $\beta$-induced oxidative stress and mitochondrial dysfunction. Journal of Alzheimer's Disease, 45(3), 933-946. https://doi.org/10.3233/ JAD-142217

Guo, C., Sun, L., Chen, X. and Zhang, D. (2013). Oxidative stress, mitochondrial damage and neurodegenerative diseases. Neural Regeneration Research, 8, 2003-2014.

Habtemariam, S. (2019). Natural products in Alzheimer's disease therapy: would old therapeutic approaches fix the broken promise of modern 
medicines? Molecules, 24(8), $1519 . \quad$ https:// doi.org/10.3390/molecules24081519

Haftek, M., Mac-Mary, S., Bitoux, M.A.L., Creidi, P., Seité, S., Rougier, A. and Humbert, P. (2008). Clinical, biometric and structural evaluation of the long-term effects of a topical treatment with ascorbic acid and madecassoside in photoaged human skin. Experimental Dermatology, 17(11), 946-952. https:// doi.org/10.1111/j.1600-0625.2008.00732.x

Hamid, A.A., Shah, Z.M., Muse, R. and Mohamed, S. (2002). Characterisation of antioxidative activities of various extracts of Centella asiatica (L) Urban. Food Chemistry, 77(4), 465-469. https://doi.org/10.1016/ S0308-8146(01)00384-3

Hampel, H., Mesulam, M.-M., Cuello, A.C., Farlow, M.R., Giacobini, E., Grossberg, G.T., Khachaturian, A.S., Vergallo, A., Cavedo, E. and Snyder, P.J. (2018). The cholinergic system in the pathophysiology and treatment of Alzheimer's disease. Brain, 141(7), 1917-1933. https:// doi.org/10.1093/brain/awy132

Hashim, P., Sidek, H., Helan, M., Sabery, A., Palanisamy, U.D. and Ilham, M. (2011). Triterpene composition and bioactivities of Centella asiatica. Molecules, 16(2), 1310-1322. https:// doi.org/10.3390/molecules 16021310

Huang, W.J., Zhang, X. and Chen, W.W. (2016). Role of oxidative stress in Alzheimer's disease. Biomedical Reports, 4(5), 519-522. https://doi.org/10.3892/ br.2016.630

Huda-Faujan, N., Noriham, A., Norrakiah, A. and Babji, A.S. (2007). Antioxidative activities of water extracts of some Malaysian herbs. ASEAN Food Journal, 14(1), 61-68.

Hussin, F., Eshkoor, S.A., Rahmat, A., Othman, F. and Akim, A. (2014). The Centella asiatica juice effects on DNA damage, apoptosis and gene expression in hepatocellular carcinoma (HCC). BMC Complementary and Alternative Medicine, 14, 32. https://doi.org/10.1186/1472-6882-14-32

Hussin, M., Abdul-Hamid, A., Mohamad, S., Saari, N., Ismail, M. and Bejo, M.H. (2007). Protective effect of Centella asiatica extract and powder on oxidative stress in rats. Food Chemistry, 100(2), 535-541. https://doi.org/10.1016/j.foodchem.2005.10.022

Idris, F.N. and Nadzir, M.M. (2017). Antimicrobial activity of Centella asiatica on Aspergillus niger and Bacillus subtilis. Chemical Engineering Transactions, 56, 1381-1386.

James, J. and Dubery, I. (2009). Pentacyclic triterpenoids from the medicinal herb, Centella asiatica (L.) Urban. Molecules, 14(10), 3922-3941. https:// doi.org/10.3390/molecules 14103922
Jamil, S.S., Nizami, Q. and Salam, M. (2007). Centella asiatica (Linn.) Urban - a review. Natural Products Radiance, 6(2), 158-170.

Jayaprakash, S.B. and Nagarajan, N. (2016). Studies on the bioactive compounds and antimicrobial activities of medicinal plant Centella asiatica (Linn). Journal of Medicinal Plants Studies, 4(5), 181-185.

Jayashree, G., Muraleedhara, G. K., Sudarslal, S. and Jacob, V. (2003). Anti-oxidant activity of Centella asiatica on lymphoma-bearing mice. Fitoterapia, 74 (5), 431-434. https://doi.org/10.1016/S0367-326X (03)00121-7

Jayathirtha, M. and Mishra, S. (2004). Preliminary immunomodulatory activities of methanol extracts of Eclipta alba and Centella asiatica. Phytomedicine, 11(4), 361-365. https:// doi.org/10.1078/0944711041495236

Joy, J. and Nair, C.K.K. (2009). Protection of DNA and membranes from gamma-radiation induced damages by Centella asiatica. Journal of Pharmacy and Pharmacology, 61(7), 941-947. https:// doi.org/10.1211/jpp.61.07.0014

Kabir, A.U., Samad, M.B., D'Costa, N.M., Akhter, F., Ahmed, A. and Hannan, J.M.A. (2014). Antihyperglycemic activity of Centella asiatica is partly mediated by carbohydrase inhibition and glucosefiber binding. BMC Complementary and Alternative Medicine, 14, 31. https://doi.org/10.1186/1472-688214-31

Kim, Y.J., Cha, H.J., Nam, K.H., Yoon, Y., Lee, H. and An, S. (2011). Centella asiatica extracts modulate hydrogen peroxide-induced senescence in human dermal fibroblasts. Experimental Dermatology, 20 (12), 998-1003. https://doi.org/10.1111/j.16000625.2011.01388.x

Kumar, A., Dogra, S. and Prakash, A. (2009). Neuroprotective effects of Centella asiatica against intracerebroventricular colchicine-induced cognitive impairment and oxidative stress. International Journal of Alzheimer's Disease, 2009, 972178. https://doi.org/10.4061/2009/972178

Kumar, A., Prakash, A. and Dogra, S. (2011). Centella asiatica attenuates D-galactose-induced cognitive impairment, oxidative and mitochondrial dysfunction in mice. International Journal of Alzheimer's Disease, 2011, $347569 . \quad$ https:// doi.org/10.4061/2011/347569

Kumar, G.P. and Khanum, F. (2012). Neuroprotective Potential of Phytochemicals. Pharmacognosy Reviews, 6(12), 81-90. https://doi.org/10.4103/09737847.99898

Kumar, M.V. and Gupta, Y. (2002). Effect of different extracts of Centella asiatica on cognition and markers of oxidative stress in rats. Journal of 
Ethnopharmacology, 79(2), 253-260. https:// doi.org/10.1016/S0378-8741(01)00394-4

Kwon, M.C., Choi, W.Y., Seo, Y.C., Kim, J.S., Yoon, C.S., Lim, H.W., Kim, H.S., Hee Ahn, J. and Lee, H.Y. (2012). Enhancement of the skin-protective activities of Centella asiatica L. Urban by a nanoencapsulation process. Journal of Biotechnology, 157(1), 100-106. https://doi.org/10.1016/ j.jbiotec.2011.08.025

Latif, M.S., Abbas, S., Kormin, F. and Mustafa, M.K. (2019). Green synthesis of plant-mediated metal nanoparticles: The role of polyphenols. Asian Journal of Pharmaceutical and Clinical Research, 12(7), 75-84. https://doi.org/10.22159/ ajpcr.2019.v12i7.33211

Li, G., Bian, G., Ren, J., Wen, L., Zhang, M. and Lü, Q. (2007). Protective effect of madecassoside against reperfusion injury after regional ischemia in rabbit heart in vivo. Yao xue xue bao = Acta Pharmaceutica Sinica, 42(5), 475-480.

Lin, L T., Liu, L.T., Chiang, L.C. and Lin, C.C. (2002). In vitro anti-hepatoma activity of fifteen natural medicines from Canada. Phytotherapy Research: An International Journal Devoted to Pharmacological and Toxicological Evaluation of Natural Product Derivatives, 16(5), 440-444. https://doi.org/10.1002/ ptr.937

Lionetto, M.G., Caricato, R., Calisi, A., Giordano, M.E. and Schettino, T. (2013). Acetylcholinesterase as a biomarker in environmental and occupational medicine: new insights and future perspectives. BioMed Research International, 2013, 321213. https://doi.org/10.1155/2013/321213

Mahalik, S., Mohanty, B. and Marandi, G. (2019). Growth Inhibitory Effects of Centella asiatica Extracts on Escherichia coli. Research and Reviews: A Journal of Microbiology and Virology, 9(2), 1-7.

Martins, R.N., Villemagne, V., Sohrabi, H.R., Chatterjee, P., Shah, T.M., Verdile, G., Fraser, P., Taddei, K., Gupta, V.B. and Rainey-Smith, S.R. (2018). Alzheimer's disease: a journey from amyloid peptides and oxidative stress, to biomarker technologies and disease prevention strategiesgains from AIBL and DIAN cohort studies. Journal of Alzheimer's Disease, 62(3), 965-992. https:// doi.org/10.3233/JAD-171145

Mathew, M. and Subramanian, S. (2014). In vitro screening for anti-cholinesterase and antioxidant activity of methanolic extracts of ayurvedic medicinal plants used for cognitive disorders. PLoS One, 9(1), e86804. https://doi.org/10.1371/ journal.pone.0086804

Mensor, L.L., Menezes, F.S., Leitão, G G., Reis, A.S., Santos, T.C.D., Coube, C.S. and Leitão, S.G. (2001).
Screening of Brazilian plant extracts for antioxidant activity by the use of DPPH free radical method. Phytotherapy Research, 15(2), 127-130. https:// doi.org/10.1002/ptr.687

Miean, K.H. and Mohamed, S. (2001). Flavonoid (myricetin, quercetin, kaempferol, luteolin, and apigenin) content of edible tropical plants. Journal of Agricultural and Food Chemistry, 49(6), 3106-3112. https://doi.org/10.1021/jf000892m

Miyazawa, M. and Yamafuji, C. (2005). Inhibition of acetylcholinesterase activity by bicyclic monoterpenoids. Journal of Agricultural and Food Chemistry, 53(5), 1765-1768. https:// doi.org/10.1021/jf040019b

Mukherjee, P.K., Kumar, V. and Houghton, P.J. (2007). Screening of Indian medicinal plants for acetylcholinesterase inhibitory activity. Phytotherapy Research: An International Journal Devoted to Pharmacological and Toxicological Evaluation of Natural Product Derivatives, 21(12), 1142-1145. https://doi.org/10.1002/ptr.2224

Nasir, M., Abdullah, J., Habsah, M., Ghani, R. and Rammes, G. (2012). Inhibitory effect of asiatic acid on acetylcholinesterase, excitatory post synapticpotential and locomotor activity. Phytomedicine, 19(3-4), 311-316. https:// doi.org/10.1016/j.phymed.2011.10.004

Nhiem, N.X., Tai, B.H., Quang, T.H., Van Kiem, P., Van Minh, C., Nam, N.H., Kim, J.-H., Im, L.-R., Lee, Y.M. and Kim, Y.H. (2011). A new ursane-type triterpenoid glycoside from Centella asiatica leaves modulates the production of nitric oxide and secretion of TNF- $\alpha$ in activated RAW 264.7 cells. Bioorganic and Medicinal Chemistry Letters, 21(6), 1777-1781. https://doi.org/10.1016/ j.bmcl.2011.01.066

Nimse, S.B. and Pal, D. (2015). Free radicals, natural antioxidants, and their reaction mechanisms. RSC Advances, 5(35), 27986-28006. https:// doi.org/10.1039/C4RA13315C

Nour, A.H., Khan, M., Sulaiman, A.Z., Batool, T., Nour, A.H., Khan, M.M. and Kormin, F. (2014). In vitro anti-acetyl cholinesterase and antioxidant activity of selected Malaysian plants. Asian Journal of Pharmaceutical and Clinical Research, 7(3), 93-97.

Odhav, B., Beekrum, S., Akula, U. and Baijnath, H. (2007). Preliminary assessment of nutritional value of traditional leafy vegetables in KwaZulu-Natal, South Africa. Journal of Food Composition and Analysis, 20(5), 430-435. https://doi.org/10.1016/ j.jfca.2006.04.015

Orhan, G., Orhan, I. and Sener, B. (2006). Recent developments in natural and synthetic drug research for Alzheimer's disease. Letters in Drug Design and 
Discovery, 3(4), 268-274.

doi.org/10.2174/157018006776743215

Orhan, I.E. (2012). Centella asiatica (L.) Urban: From

Traditional Medicine to Modern Medicine with

Neuroprotective Potential. Evidence-Based Complementary and Alternative Medicine, 2012, 946259. https://doi.org/10.1155/2012/946259

Pan, Y., Abd-Rashid, B.A., Ismail, Z., Ismail, R., Mak, J. W., Pook, P.C., Er, H.M. and Ong, C.E. (2010). In vitro modulatory effects on three major human cytochrome $\mathrm{P} 450$ enzymes by multiple active constituents and extracts of Centella asiatica. Journal of Ethnopharmacology, 130(2), 275-283. https://doi.org/10.1016/j.jep.2010.05.002

Patterson, C. (2018). World Alzheimer report 2018: the state of the art of dementia research: new frontiers. London, UK: Alzheimer's Disease International (ADI).

Phaniendra, A., Jestadi, D.B. and Periyasamy, L. (2015). Free radicals: properties, sources, targets, and their implication in various diseases. Indian Journal of Clinical Biochemistry, 30(1), 11-26. https:// doi.org/10.1007/s12291-014-0446-0

Pingale, S.S. (2008). Evaluation of effect of Centella asiatica on CCL4 induced rat liver damage. Pharmacologyonline, 3, 537-543.

Pittella, F., Dutra, R., Junior, D., Lopes, M.T. and Barbosa, N. (2009). Antioxidant and cytotoxic activities of Centella asiatica (L) Urb. International Journal of Molecular Sciences, 10(9), 3713-3721. https://doi.org/10.3390/ijms10093713

Pragada, R., Veeravalli, K., Chowdary, K. and Routhu, K. (2004). Cardioprotective activity of Hydrocotyle asiatica L. in ischemia-reperfusion induced myocardial infarction in rats. Journal of Ethnopharmacology, 93(1), 105-108. https:// doi.org/10.1016/j.jep.2004.03.025

Prakash, A. and Kumar, A. (2013). Mitoprotective effect of Centella asiatica against aluminum-induced neurotoxicity in rats: possible relevance to its antioxidant and anti-apoptosis mechanism. Neurological Sciences, 34(8), 1403-1409. https://doi.org/10.1007/ s10072-012-1252-1

Prakash, V., Jaiswal, N. and Srivastava, M. (2017). A review on medicinal properties of Centella asiatica. Asian Journal of Pharmaceutical and Clinical Research, 10(10), 69-74. https://doi.org/10.22159/ ajpcr.2017.v10i10.20760

Punturee, K., Wild, C.P., Kasinrerk, W. and Vinitketkumnuen, U. (2005). Immunomodulatory activities of Centella asiatica and Rhinacanthus nasutus extracts. Asian Pacific Journal of Cancer Prevention: APJCP, 6(3), 396-400.
Ramachandran, V. and Saravanan, R. (2013). Efficacy of asiatic acid, a pentacyclic triterpene on attenuating the key enzymes activities of carbohydrate metabolism in streptozotocin-induced diabetic rats. Phytomedicine, 20(3-4), 230-236. https:// doi.org/10.1016/j.phymed.2012.09.023

Rao, M.V.G. and Mastan, S. (2007). Antidiabetic effects of methanolic extract of Centella asiatica (Linn.) on induced hyperglycemic rats. Biosciences Biotechnology Research Asia, 4(2), 721-724.

Rao, S.B., Chetana, M. and Devi, P.U. (2005). Centella asiatica treatment during postnatal period enhances learning and memory in mice. Physiology and Behavior, 86(4), 449-457. https://doi.org/10.1016/ j.physbeh.2005.07.019

Roy, D.C., Barman, S.K. and Shaik, M.M. (2013). Current updates on Centella asiatica: phytochemistry, pharmacology and traditional uses. Medicinal Plant Research, 3(4), 20-36.

Ruszymah, B.H.I., Chowdhury, S.R., Manan, N.A.B.A., Fong, O.S., Adenan, M.I. and Saim, A.B. (2012). Aqueous extract of Centella asiatica promotes corneal epithelium wound healing in vitro. Journal of Ethnopharmacology, 140(2), 333-338. https:// doi.org/10.1016/j.jep.2012.01.023

Sadigh-Eteghad, S., Sabermarouf, B., Majdi, A., Talebi, M., Farhoudi, M. and Mahmoudi, J. (2015). Amyloid -beta: a crucial factor in Alzheimer's disease. Medical Principles and Practice, 24(1), 1-10. https:// doi.org/10.1159/000369101

Saha, S., Guria, T., Singha, T. and Maity, T.K. (2013). Evaluation of analgesic and anti-inflammatory activity of chloroform and methanol extracts of Centella asiatica Linn. International Scholarly Research Notices, 2013, 789613. https:// doi.org/10.1155/2013/789613

Sairam, K., Rao, C.V. and Goel, R. (2001). Effect of Centella asiatica Linn on physical and chemical factors induced gastric ulceration and secretion in rats. Indian Journal of Experimental Biology, 39(2), 137-142.

Sarumathi, A. and Saravanan, N. (2013). A study on the hematological parameters and brain acetylcholine esterase activity in immobilization induced stress and co-treatment with Centella asiatica leaves extract to Wistar rats. International Journal of Nutrition, Pharmacology, Neurological Diseases, 3 (2), 102-107. https://doi.org/10.4103/22310738.112829

Sberna, G., Sáez-Valero, J., Beyreuther, K., Masters, C.L. and Small, D.H. (1997). The amyloid $\beta$-protein of Alzheimer's disease increases acetylcholinesterase expression by increasing intracellular calcium in embryonal carcinoma P19 cells. Journal of 
Neurochemistry, 69(3), 1177-1184. https:// doi.org/10.1046/j.1471-4159.1997.69031177.x

Selvam, D.A., Ng, C.H., Razik, R.M., Al-Dhalli, S. and Shaari, K. (2019). Effects of extraction methods on antibacterial activity of Centella asiatica leaves against pathogenic Staphylococcus aureus and Escherichia coli. International Journal of Medical Toxicology and Legal Medicine, 22(1 and 2), 172178. 4614.2019.00037.8

Sharma, J. and Sharma, R. (2002). Radioprotection of Swiss albino mouse by Centella asiatica extract. Phytotherapy Research: An International Journal Devoted to Pharmacological and Toxicological Evaluation of Natural Product Derivatives, 16(8), 785-786. https://doi.org/10.1002/ptr.1069

Sharma, R. and Sharma, J. (2005). Modification of gamma ray induced changes in the mouse hepatocytes by Centella asiatica extract: in vivo studies. Phytotherapy Research: An International Journal Devoted to Pharmacological and Toxicological Evaluation of Natural Product Derivatives, 19(7), 605-611. https://doi.org/10.1002/ ptr.1684

Shetty, B.S., Udupa, S., Udupa, A. and Somayaji, S. (2006). Effect of Centella asiatica L (Umbelliferae) on normal and dexamethasone-suppressed wound healing in Wistar Albino rats. The International Journal of Lower Extremity Wounds, 5(3), 137-143. https://doi.org/10.1177/1534734606291313

Shinomol, G.K. (2008a). Effect of Centella asiatica leaf powder on oxidative markers in brain regions of prepubertal mice in vivo and its in vitro efficacy to ameliorate 3-NPA-induced oxidative stress in mitochondria. Phytomedicine, 15(11), 971-984. https://doi.org/10.1016/j.phymed.2008.04.010

Shinomol, G.K. (2008b). Prophylactic neuroprotective property of Centella asiatica against 3nitropropionic acid induced oxidative stress and mitochondrial dysfunctions in brain regions of prepubertal mice. Neurotoxicology, 29(6), 948-957. https://doi.org/10.1016/j.neuro.2008.09.009

Shinomol, G.K. and Ravikumar, H. (2010). Prophylaxis with Centella asiatica confers protection to prepubertal mice against 3-nitropropionic-acidinduced oxidative stress in brain. Phytotherapy Research, 24(6), 885-892. https://doi.org/10.1002/ ptr.3042

Shobi, V. and Goel, H. (2001). Protection against radiation-induced conditioned taste aversion by Centella asiatica. Physiology and Behavior, 73(1-2), 19-23. https://doi.org/10.1016/S0031-9384(01) 00434-6
Shukla, S.D., Bhatnagar, M. and Khurana, S. (2012). Critical evaluation of ayurvedic plants for stimulating intrinsic antioxidant response. Frontiers in Neuroscience, 6, 112. https://doi.org/10.3389/ fnins.2012.00112

Siddiqui, B., Aslam, H., Ali, S., Khan, S. and Begum, S. (2007). Chemical constituents of Centella asiatica. Journal of Asian Natural Products Research, 9(4), 407-414.

https:// doi.org/10.1080/10286020600782454

Singh, B. and Rastogi, R. (1969). A reinvestigation of the triterpenes of Centella asiatica. Phytochemistry, 8(5), 917-921. https://doi.org/10.1016/S0031-9422 (00)85884-7

Soumyanath, A., Zhong, Y.-P., Henson, E., Wadsworth, T., Bishop, J., Gold, B. G. and Quinn, J.F. (2012). Centella asiatica extract improves behavioral deficits in a mouse model of Alzheimer's disease: investigation of a possible mechanism of action. International Journal of Alzheimer's Disease, 2012, 381974. https://doi.org/10.1155/2012/381974

Subathra, M., Shila, S., Devi, M.A. and Panneerselvam, C. (2005). Emerging role of Centella asiatica in improving age-related neurological antioxidant status. Experimental Gerontology, 40(8-9), 707-715. https://doi.org/10.1016/j.exger.2005.06.001

Sultzer, D.L. (2018). Cognitive ageing and Alzheimer's disease: the cholinergic system redux. Brain, 141(3), 626-628. https://doi.org/10.1093/brain/awy040

Supkamonseni, N., Thinkratok, A., Meksuriyen, D. and Srisawat, R. (2014). Hypolipidemic and hypoglycemic effects of Centella asiatica (L.) extract in vitro and in vivo. Indian Journal of Experimental Biology, 52(10), 965-971.

Tönnies, E. and Trushina, E. (2017). Oxidative stress, synaptic dysfunction, and Alzheimer's disease. Journal of Alzheimer's Disease, 57(4), 1105-1121. https://doi.org/10.3233/JAD-161088

Ullah, M.O., Sultana, S., Haque, A. and Tasmin, S. (2009). Antimicrobial, cytotoxic and antioxidant activity of Centella asiatica. European Journal of Scientific Research, 30(2), 260-264.

Veerendra Kumar, M. and Gupta, Y. (2003). Effect of Centella asiatica on cognition and oxidative stress in an intracerebroventricular streptozotocin model of Alzheimer's disease in rats. Clinical and Experimental Pharmacology and Physiology, 30(56), 336-342. https://doi.org/10.1046/j.14401681.2003.03842.x

Viera, V., Piovesan, N., Rodrigues, J., de O Mello, R., Prestes, R., dos Santos, R., de A Vaucher, R., Hautrive, T. and Kubota, E. (2017). Extraction of phenolic compounds and evaluation of the 
antioxidant and antimicrobial capacity of red onion skin (Allium cepa L.). International Food Research Journal, 24(3), 990-999.

Visweswari, G., Prasad, K.S., Chetan, P.S., Lokanatha, V. and Rajendra, W. (2010). Evaluation of the anticonvulsant effect of Centella asiatica (gotu kola) in pentylenetetrazol-induced seizures with respect to cholinergic neurotransmission. Epilepsy and Behavior, 17(3), 332-335. https://doi.org/10.1016/ j.yebeh.2010.01.002

Vohra, K., Pal, G., Gupta, V.K., Singh, S. and Bansal, Y. (2011). An insight on Centella asiatica Linn.: A review on recent research. Pharmacologyonline, 2, 440-463.

Wan, J., Gong, X., Jiang, R., Zhang, Z. and Zhang, L. (2013). Antipyretic and anti-inflammatory effects of asiaticoside in lipopolysaccharide-treated rat through up-regulation of heme oxygenase-1. Phytotherapy Research, 27(8), 1136-1142. https://doi.org/10.1002/ ptr.4838

Wanakhachornkrai, O., Pongrakhananon, V., Chunhacha, P., Wanasuntronwong, A., Vattanajun, A., Tantisira, B., Chanvorachote, P. and Tantisira, M.H. (2013). Neuritogenic effect of standardized extract of Centella asiatica ECa233 on human neuroblastoma cells. BMC Complementary and Alternative Medicine, 13, 204. https:// doi.org/10.1186/1472-6882-13-204

Wanasuntronwong, A., Tantisira, M.H., Tantisira, B. and Watanabe, H. (2012). Anxiolytic effects of standardized extract of Centella asiatica (ECa 233) after chronic immobilization stress in mice. Journal of Ethnopharmacology, 143(2), 579-585. https:// doi.org/10.1016/j.jep.2012.07.010

Wang, X.S., Liu, L. and Fang, J.N. (2005). Immunological activities and structure of pectin from Centella asiatica. Carbohydrate Polymers, 60 (1), 95-101. https://doi.org/10.1016/ j.carbpol.2004.11.031

Wider, C. and Wszolek, Z.K. (2008). Etiology and pathophysiology of frontotemporal dementia, Parkinson disease and Alzheimer disease: lessons from genetic studies. Neurodegenerative Diseases, 5 (3-4), 122-125. https://doi.org/10.1159/000113680

Wojsiat, J., Zoltowska, K.M., Laskowska-Kaszub, K. and Wojda, U. (2018). Oxidant/antioxidant imbalance in Alzheimer's disease: therapeutic and diagnostic prospects. Oxidative Medicine and Cellular Longevity, 2018, 6435861. https:// doi.org/10.1155/2018/6435861

Xu, M.-F., Xiong, Y.-Y., Liu, J.-K., Qian, J.-J., Zhu, L. and Gao, J. (2012). Asiatic acid, a pentacyclic triterpene in Centella asiatica, attenuates glutamateinduced cognitive deficits in mice and apoptosis in
SH-SY5Y cells. Acta Pharmacologica Sinica, 33(5), 578-587. https://doi.org/10.1038/aps.2012.3

$\mathrm{Xu}$, Y., Cao, Z., Khan, I. and Luo, Y. (2008). Gotu Kola (Centella asiatica) extract enhances phosphorylation of cyclic AMP response element binding protein in neuroblastoma cells expressing amyloid beta peptide. Journal of Alzheimer's Disease, 13(3), 341349. https://doi.org/10.3233/JAD-2008-13311

Yasurin, P., Sriariyanun, M. and Phusantisampan, T. (2016). the bioavailability activity of Centella asiatica. King Mongkut's University of Technology North Bangkok International Journal of Applied Science and Technology, 9(1), 1-9. https:// doi.org/10.14416/j.ijast.2015.11.001

Zaidan, M., Noor Rain, A., Badrul, A., Adlin, A., Norazah, A. and Zakiah, I. (2005). In vitro screening of five local medicinal plants for antibacterial activity using disc diffusion method. Tropical Biomedicine, 22(2), 165-170.

Zainol Abidin, N.A., Kormin, F., Mohamed Anuar, N.A.F. and Zainol Abidin, N.A. (2020). Development and evaluation of polyherbal formulation for memory enhancement: study on its antioxidant properties and synergistic effects. Food Research, 4(2), 431-440. https://doi.org/10.26656/ fr.2017.4(2).258

Zainol, M., Abd-Hamid, A., Yusof, S. and Muse, R. (2003). Antioxidative activity and total phenolic compounds of leaf, root and petiole of four accessions of Centella asiatica (L.) Urban. Food Chemistry, 81(4), 575-581. https://doi.org/10.1016/ S0308-8146(02)00498-3

Zhao, Y., Shu, P., Zhang, Y., Lin, L., Zhou, H., Xu, Z., Suo, D., Xie, A. and Jin, X. (2014). Effect of Centella asiatica on oxidative stress and lipid metabolism in hyperlipidemic animal models. Oxidative Medicine and Cellular Longevity, 2014, 154295. https://doi.org/10.1155/2014/154295

Zhao, Y. and Zhao, B. (2013). Oxidative stress and the pathogenesis of Alzheimer's disease. Oxidative Medicine and Cellular Longevity, 2013, 316523. https://doi.org/10.1155/2013/316523 